\title{
DieselHouse*
}

解説

Explanation
- Wonderland for All, Young and Old, with an Interest in

Technology and History

Peter D. Petersen**

The smell of metal, fuel, oil, and the mix of history and contemporary technology greets you when entering the doors of DieselHouse in Copenhagen, Denmark. The old historic building spans two centuries of maritime and industrial history presented in ways never thought of in the early era of the diesel engine.

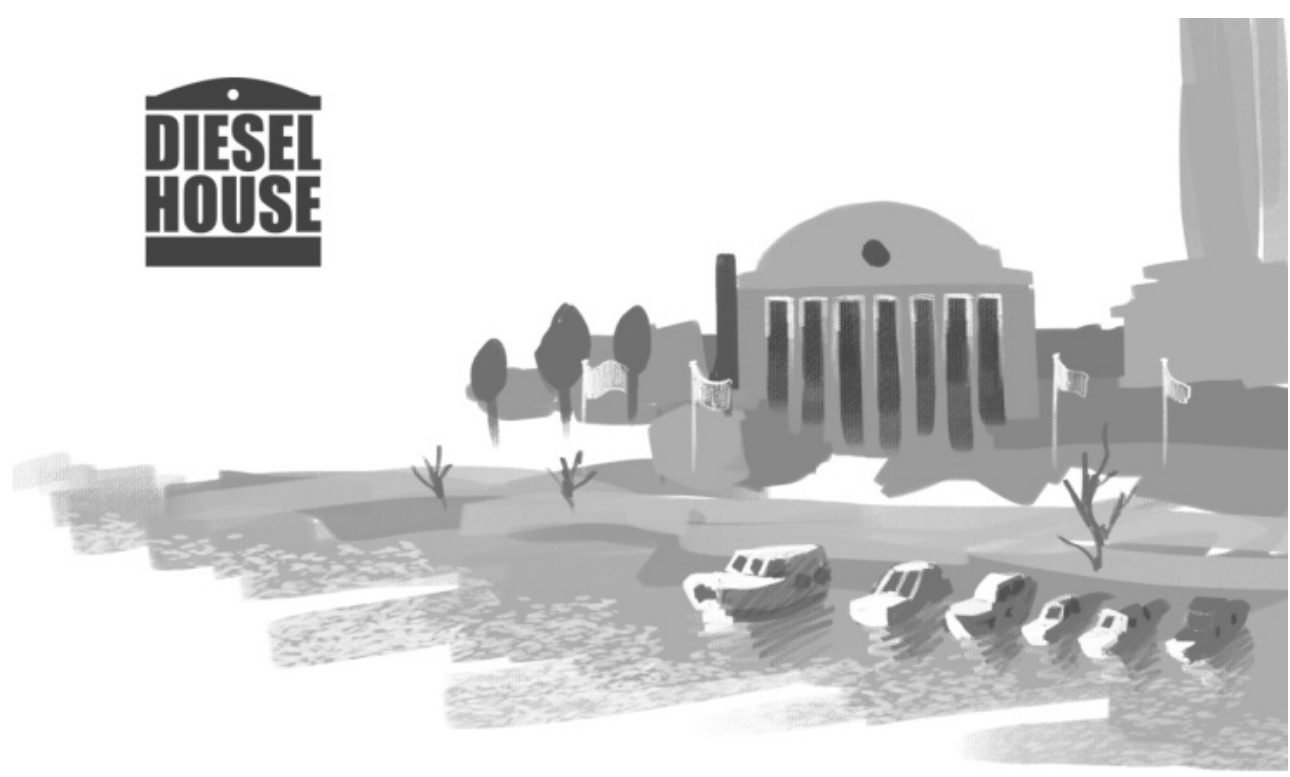

Fig. 1 DieselHouse in the year 2017 drawn by artist Lisbeth Møller Fly

\section{The history of DieselHouse}

The building was erected in 1932 during the industrialisation of Denmark. At the time, it was still surrounded by a drying ground for fishing nets of local fishermen. The area hosted an environment displaying side by side the old craftsmanship practised by the fishermen and the effect of the industrialisation, the H.C Ørsted power plant. This area is a unique part of Copenhagen still under development today.

In 1933 the H.C. Ørsted power plant, accommodating the largest diesel engine ever built at that time, was inaugurated by the Danish prime minister.

*Received October 20, 2017
The original purpose of the engine was to cover peak loads in the electricity consumption in the morning hours and during the afternoon when people returned from work. The diesel engine driven generator was perfectly suited for covering the varying peak loads, as it was more easily regulated than the steam turbines in the power plant.

The diesel engine contributed greatly to the electrification of Denmark and the rest of the world. It played a vital role in changing the everyday lives of many people. This is what DieselHouse is about. Arguably, the invention of the diesel engine and its further development had the largest impact on the industrial development in the $20^{\text {th }}$ century.

**MAN Diesel \& Turbo, Copenhagen, Denmark 


\section{A unique heritage is passed on in DieselHouse}

DieselHouse takes you on a journey into the history of diesel technology. Since 2006 it has been a knowledge centre for young and old, for professional marine engineers, and for the general public with an interest in technology. In a number of exciting displays, the past, present, and future of diesel technology are unveiled for the visitor to explore.

The maritime, technological, and cultural heritage is mediated through channels not by far invented when the large combustion engine was developed. In the 1920's, the prevailing tools were the knowledge of skilled engineers, slide rulers, rulers, and pencils.

The new diesel technology had a significant impact on society. During the industrialisation, the diesel engine became increasingly important within a number of areas/trades providing the society with more commodities, materials as well as electricity. The diesel engine started to propel ferries, trains, lorries and construction and industrial machinery of all kinds.

The diesel engine outdid the steam engine during the industrialisation. The first Danish public power plant was erected in 1891 in Odense, where four steam-powered dynamos providing $300 \mathrm{~kW}$ supplied light to the city of Odense. In 1930 Denmark had around 500 small power plants. Most of these produced DC using generator driven dynamos. In the beginning the load of the power plants was mainly light installations.

Spanning three floors and two centuries, the exhibition tells the story of this development. The extensive historical timeline on the ground floor gives the visitor an opportunity to dwell on the milestones of the two centuries.

On the ground floor of DieselHouse, four large engines: The H.C. Ørsted Engine, B\&W No. 1, Holeby No. 1 and a Bur-wain engine, set the scene for a guided tour into the history and development of the diesel engine and diesel technology.

\section{The H.C. Ørsted engine}

The H.C Ørsted engine (Figs. 2 and 3), which plays a central role of the exhibition, was a mastodon in 1933, 12.5 metres high and an impressive 24.5 metres long.

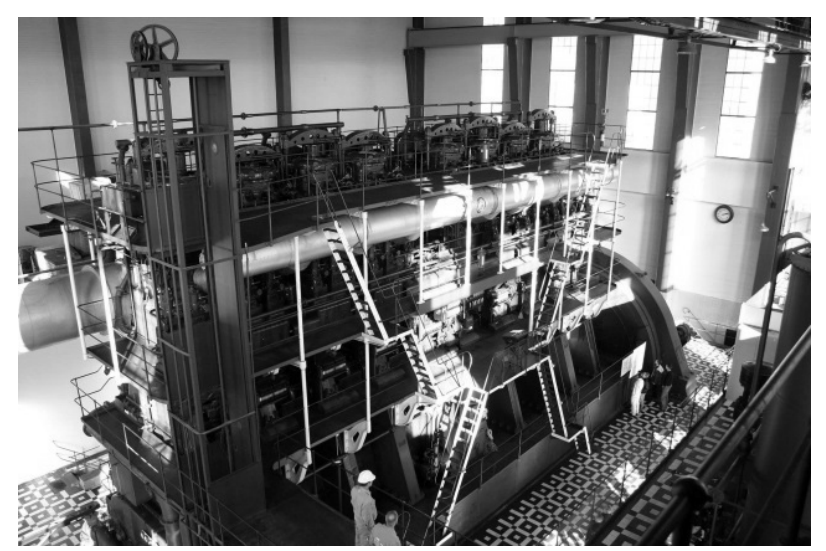

Fig. 2 The H.C. Ørsted engine, B\&W No. 2000

In 1933, the two-stroke, double-acting engine was 50\% larger than any engine ever built. For the next 30 years to come, it remained the largest two-stroke engine in the world, see engine facts in Table 1.

Table 1 The H.C. Ørsted engine of 1933

\begin{tabular}{|c|c|}
\hline Number of cylinders & 8 \\
\hline Bore/mm & 840 \\
\hline Stroke/mm & 1,500 \\
\hline Weight/t & 1,400 \\
\hline Revolutions per minute/rpm & 115 \\
\hline Power output/HP & 22,500 \\
\hline Power output generator/kW & 15,000 \\
\hline
\end{tabular}

Impressively, 70 years later the engine was still operational. It was up and running in 2003 during an extensive power outage on the eastern part of Denmark and the south of Sweden. .

The engine began its second life in 2006 as a memorial to the industrial époque and as a testimonial to the engineers and workers of Burmeister \& Wain (B\&W) of that time.

Seeing and hearing the start of the large engine is a unique experience that leaves one humble in the recognition of what the engineers achieved in 1933. The start-up of 
the large engine can be experienced in

DieselHouse twice a month.

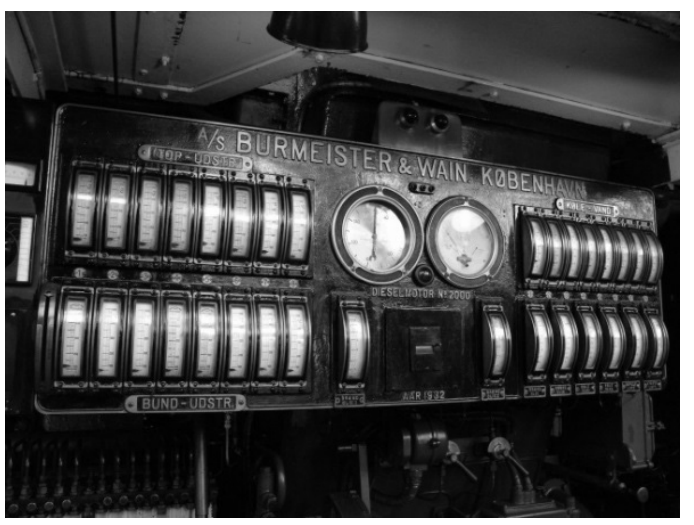

Fig. 3 Gauges on the H. C. Ørsted engine, B\&W No. 2000

\section{B\&W No. 1, DM140}

Another great milestone in Danish engine development is the B\&W No. 1 (Fig. 4).

B\&W was among the first few companies who had the foresight to acquire the patent of Rudolf Diesel. In 1898 he transferred the Danish patent rights to his famous engine to $\mathrm{B} \& \mathrm{~W}$. An engine was built and tested, and in 1904 the first diesel engine produced by B\&W was delivered to the carriage factory of $\mathrm{N}$. Larsen in Copenhagen.

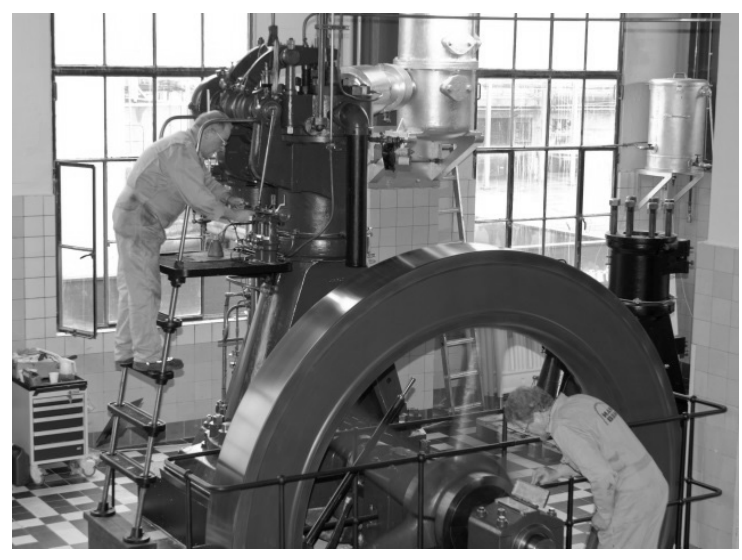

Fig.4 B\&W No. 1, DM140

The engine is a four-stroke trunk engine with the characteristics given in Table 2 .
Table 2 B\&W No.1 of 1904

\begin{tabular}{|c|c|}
\hline Number of cylinders & 1 \\
\hline Bore/mm & 320 \\
\hline Stroke/mm & 490 \\
\hline Weight/t & $15-16$ \\
\hline Revolutions per minute/rpm & 180 \\
\hline Power output/BHP & 40 \\
\hline
\end{tabular}

The engine drove a dynamo producing light at the carriage factory, and it was equipped with a driveshaft to drive the machine tools. After 20 years of service at the factory, the engine was dismantled and moved to a draining plant where it drove a large water pump.

B\&W No. 1 worked reliably for 40 or so years at a number of different companies before it returned to B\&W in 1943. The slow and steady, deep rumpling of this engine can be experienced in DieselHouse when the skilled staff starts the engine.

Holeby No. 1

The first engine from Holeby was produced in 1909 by Holeby Engine Works in the southern part of Denmark.

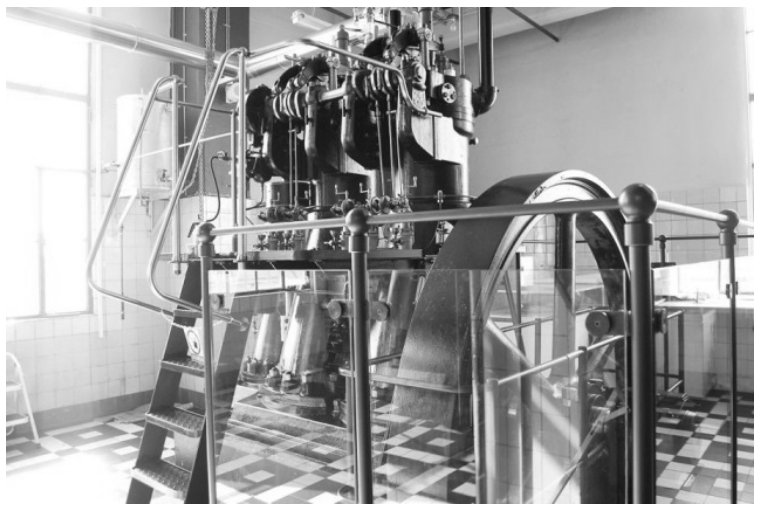

Fig.5 Holeby No. 1

Holeby No. 1 is a four-stroke, two-cylinder trunk engine with the characteristics given in Table 3.

Table 3 Holeby No. 1 of 1909

\begin{tabular}{|c|c|}
\hline Number of cylinders & 2 \\
\hline Bore/mm & 277 \\
\hline Stroke/mm & 410 \\
\hline Revolutions per minute/rpm & 250 \\
\hline Power output/BHP & 60 \\
\hline
\end{tabular}


In this rural part of southern Denmark, the trend was also towards generators delivering the electricity supply. The engine was originally installed at the local power station to power the machine tools at the works. The engine drove a generator on this site for almost thirty years after which it was retired in the late sixties.

The widespread application of the Holeby engine counts various trades: spinning mills, textile factories, chocolate factories, joineries, engine works and ship propulsion.

This engine laid the foundation to later engine series from Holeby Engine Works. In the beginning, the development was focused on stationary engines, but in 1914 the first marine engine saw the light of the day.

The company Holeby Engine Works was acquired by B\&W in 1930 .

\section{Bur-Wain engine}

The smallest engine type in the exhibition, the Bur-Wain diesel engine (Fig. 5), was produced by B\&W during the years 1938-1948.

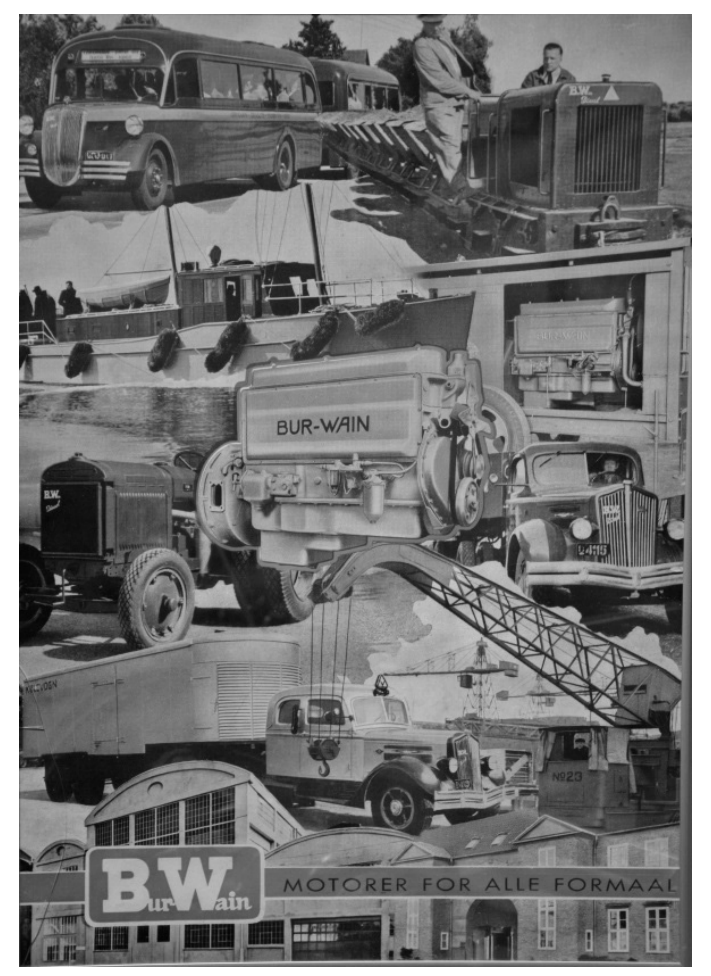

Fig. 6 Bur-Wain marketing brochure, "Engines For All Purposes"
It is a four-stroke engine (see Table 4) primarily used in trucks and buses, but also for shunting engines at the Danish State Railways (DSB) and smaller boats.

Table 4 Bur-Wain diesel 6A13D of 1945

\begin{tabular}{|c|c|}
\hline Number of cylinders & 6 \\
\hline Bore/mm & 110 \\
\hline Stroke/mm & 135 \\
\hline Revolutions per minute/rpm & 2000 \\
\hline Power output/SHP & 105 \\
\hline
\end{tabular}

The engine on display used to power a motorboat and was built from spare parts during the years $1995-1997$.

\section{B\&W - the window to two centuries of technological changes}

Climbing the stairs, one embarks on a cultural and historical narrative about the company B\&W. The company that had started out as a forging shop in 1843 later became the largest working place in Denmark.

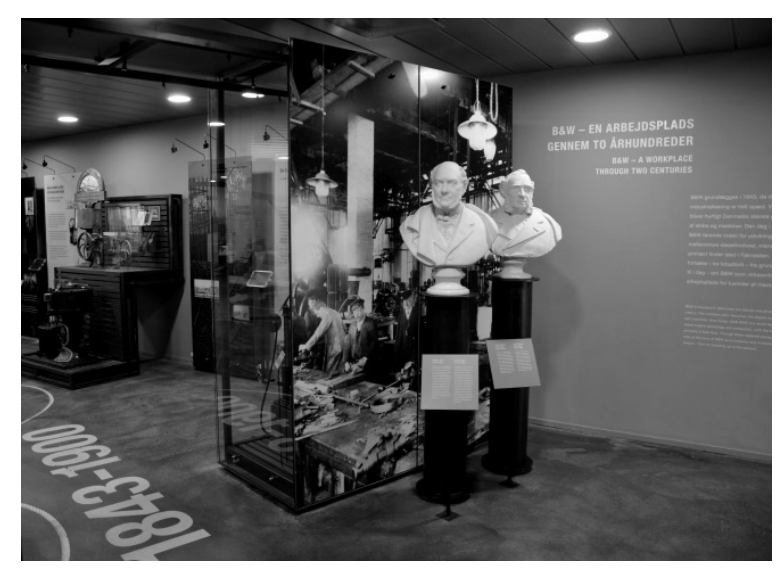

Fig. 7 Willian Wain and Carl Christian Burmeister

One of the events that had a major impact on the later history of B\&W started in 1894, when B\&W was approached by Rudolf Diesel in his attempt to promote his diesel engine project. In 1897 the technical director of $\mathrm{B} \& \mathrm{~W}$ travelled to Augsburg to experience the testing of the four-stroke diesel engine under development by Rudolf Diesel. In 1898, Rudolf Diesel transferred the Danish patent rights to B\&W. 
The history that unfolds is not just one about a technical major breakthrough following the acquisition of the patent rights, but also one of a more cultural perspective, the life and changing conditions for the working class.

\section{M/S Selandia - the ship that changed} the world

The M/S Selandia, pictured in Fig. 8, was the world's first ocean-going diesel-powered ship. It was built by B\&W and delivered to the East Asiatic Company in 1912.

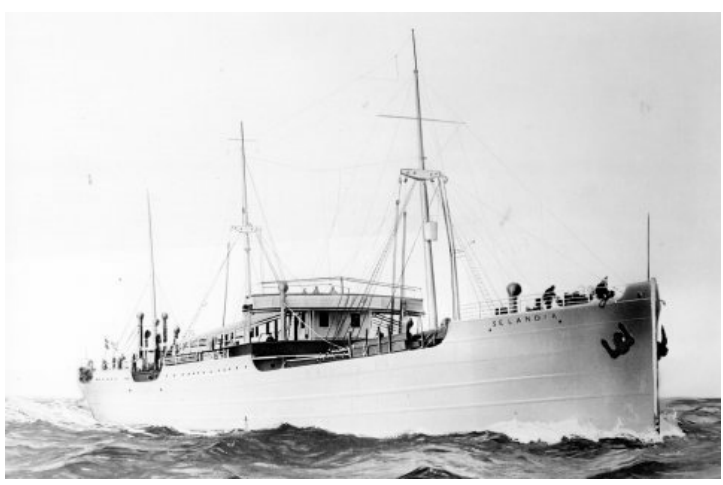

Fig. 8 M/S Selandia

Selandia's maiden voyage took her from Copenhagen in Denmark to Great Britain, Belgium, Italy, Sri Lanka, Malaysia, Singapore and Thailand. The voyage included a large number of highly esteemed visitors, including the Danish royal family and Winston Churchill.

Until then, only coal burning steamships had been travelling the seas. Selandia was propelled by two eight-cylinder four-stroke main engines of the type: B\&W, $8150 \mathrm{X}$, see Fig. 9. While the engine was based on the first engine of 1904, the marine edition of this engine had to be reversible as well.

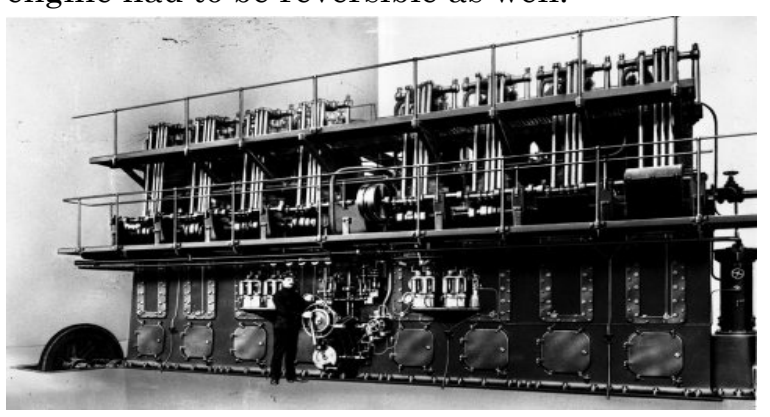

The exhibition provides you with the feeling of grandiosity, a feeling that anyone who experienced the Selandia must have felt. See different effects from M/S Selandia in Fig. 10.
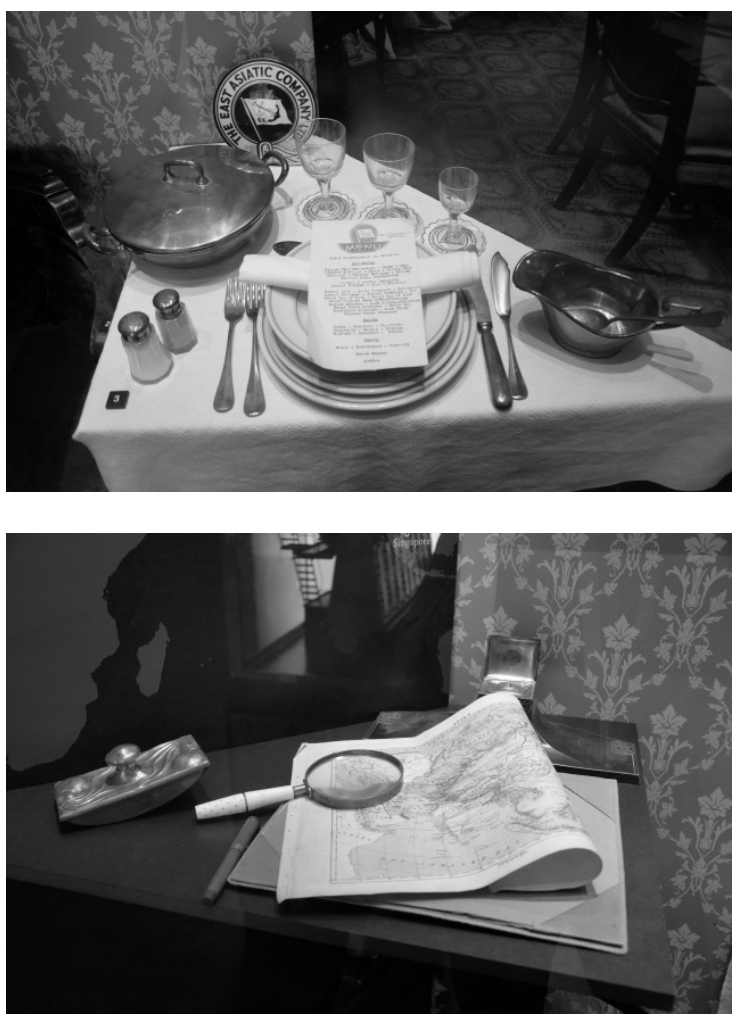

Fig. 10 Effects from M/S Selandia

30 years later, Selandia was wrecked near Yokohama in Japan.

5. Diesel engine technology of today

The journey ends on the third floor with the engine technology of today. While the journey through DieselHouse ends here, the engineers at MAN Diesel \& Turbo continue to develop and optimise the engine to suit the varying demands of today.

One of the urgent challenges today is the combustion of environmentally friendly fuels.

The research leading to an environmentally friendly, efficient and reliable two-stroke engine continues, resting on the shoulders of the pioneering engineers of 1912 .

Fig. 9 Main engine: B\&W 8150X 


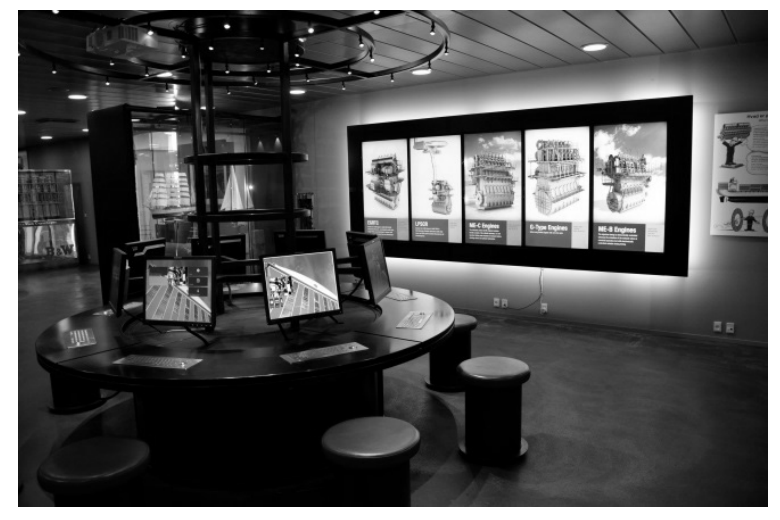

Fig. 11 Innovation floor

Based on the engine technology of 1904, the two-stroke engine has been developed to fulfil the more stringent emission requirements of 2017. One of the benefits of the MAN B\&W engine is the ability to combust almost any type of fuel oil. The latest of these encompass methanol, ethanol and methane.

The latest display in DieselHouse shows live positions of vessels equipped with an MAN $\mathrm{B} \& \mathrm{~W}$ engine navigating the waters around Denmark. Every 20 seconds, the ship name and type, IMO number, and engine description appear on the screen, see Fig. 12.

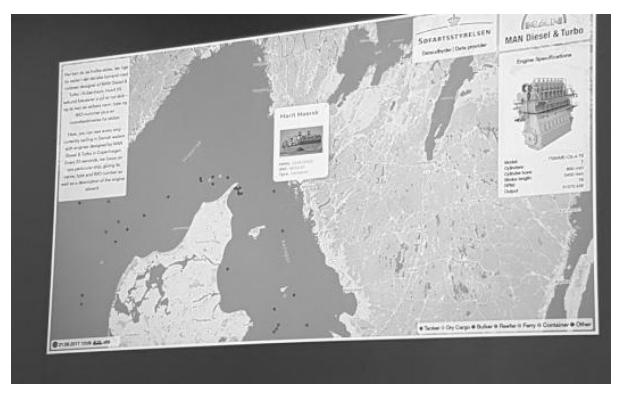

Fig. 12 Live display of vessels with an MAN B\&W engine

\section{Information about DieselHouse}

DieselHouse was founded in 2006 as a corporation between the Museum of Copenhagen and MAN B\&W Diesel.

The modernisation and day-to-day operation is funded by MAN Diesel \& Turbo and managed by Lars Peter Olsen. The staff at DieselHouse possesses a comprehensive knowledge about DieselHouse, B\&W and MAN Diesel \& Turbo, and they are always ready to tell about the engines or the exhibition.

MAN Diesel \& Turbo supports DieselHouse to fulfil their social responsibilities towards the young people, school classes, and marine engineer students in conveying the technical and historical legacy.

Follow DieselHouse on Facebook, YouTube and Twitter.

\section{http://www.dieselhouse.dk/en/}

You can book guided tours of DieselHouse on the webpage.

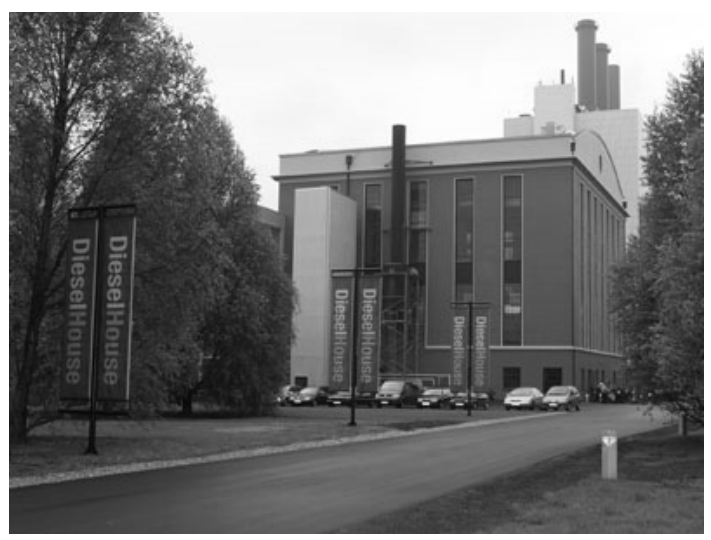

Fig. 13 DieselHouse

You can find more information about M/S Selandia here: http://selandia100.dk/

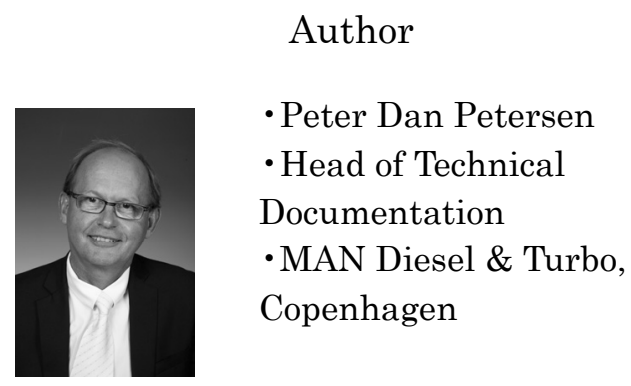

Peter Dan Petersen has been employed with MAN Diesel \& Turbo for more than 30 years. As well as developing technical documentation of the future, he also has a great interest and knowledge of the history of the company behind MAN Diesel \& Turbo. He is the fifth generation to work for the company and has been one of the founders of DieselHouse. 